\title{
Study Subject Ultrasound Image
}

National Cancer Institute

\section{Source}

National Cancer Institute. Study Subject Ultrasound Image. NCI Thesaurus. Code

C115619.

A ultrasound image taken of a study participant for use in a clinical trial. 